\title{
Analisis Sosial Ekonomi Pembentuk Tipologi Wilayah Peri Urban Kecamatan Sungai Raya, Kabupaten Kubu Raya
}

\author{
Social Economic Analysis in Establishing the Typology of The Peri Urban Area \\ in Sungai Raya District, Kubu Raya Regency
}

\section{Nana Novita Pratiwi ${ }^{1}$}

Program Studi Perencanaan Wilayah dan Kota, Universitas Tanjungpura, Pontianak, Indonesia

\section{Agustiah Wulandari}

Program Studi Perencanaan Wilayah dan Kota, Universitas Tanjungpura, Pontianak, Indonesia

\author{
Hukma Zulfinanda \\ Institut Teknologi Bandung, Bandung, Indonesia
}

Artikel Masuk : 1 September 2021

Artikel Diterima : 5 November 2021

Tersedia Online : 31 Desember 2021

\begin{abstract}
Abstrak: Kecamatan Sungai Raya merupakan salah satu wilayah peri urban dari Kota Pontianak sebagai kota inti. Sebagai ibukota provinsi, Kota Pontianak memiliki dinamika pembangunan yang tinggi sehingga memberikan dampak terhadap perkembangan di Kecamatan Sungai Raya sebagai wilayah peri urban yang berbatasan langsung. Salah satu dampak yang ditimbulkan adalah aspek sosial ekonomi. Secara umum, kondisi sosial ekonomi di Kecamatan Sungai Raya telah mengalami perubahan dari sifat agaris menjadi nonagraris. Selain itu, pertumbuhan penduduk di Kecamatan Sungai Raya juga mengalami peningkatan selama lima tahun terakhir. Perkembangan tersebut akan menjadi tidak terkendali tanpa perlakuan yang tepat. Penelitian ini bertujuan untuk mengidentifikasi tipologi wilayah berdasarkan aspek sosial ekonomi di Kecamatan Sungai Raya. Metode yang digunakan adalah analisis scoring yang menghasilkan tiga tipologi, yaitu peri urban primer, sekunder, dan rural peri urban. Berdasarkan hasil analisis diketahui bahwa mata pencaharian, indeks ketahanan ekonomi, pertumbuhan serta kepadatan penduduk menunjukan keterkaitan yang relevan antara kondisi wilayah peri urban dalam mencirikan karakter perkotaan dan perdesaan. Hal ini dibuktikan berdasarkan nilai penyimpangan korelasi antara variabel tersebut yaitu $<50 \%$. Selanjutnya, analisis skoring menghasilkan sebanyak $35 \%$ wilayah Kecamatan Sungai Raya (tujuh desa) tergolong dalam tipologi peri urban primer, 10\% (dua desa) masuk ke dalam tipologi peri urban sekunder dan 55\% (sebelas desa) merupakan rural peri urban. Dari persebaran tipologi mengindikasikan bahwa jarak dengan kota inti (Kota Pontianak) sangat berpengaruh terhadap terbentuknya tipologi wilayah peri urban.
\end{abstract}

Kata Kunci: peri urban; tipologi wilayah; sosial ekonomi; Kecamatan Sungai Raya

\footnotetext{
${ }^{1}$ Korespondensi Penulis: Universitas Tanjungpura, Pontianak, Kalimantan Barat, Indonesia

Email: nananovita@teknik.untan.ac.id
} 


\title{
307 Analisis Sosial Ekonomi Pembentuk Tipologi Wilayah Peri Urban Kecamatan Sungai Raya ...
}

\begin{abstract}
Sungai Raya sub-district is one of a peri-urban areas of Pontianak City as an urban core. As the provincial capital, Pontianak City has a high dynamic of development that has an impact on the development of Sungai Raya Subdistrict as a peri-urban area with direct borders. One of the impacts is the socio-economic aspect. In general, the socio-economic conditions in Sungai Raya District have changed from an agricultural to non-agricultural character. In addition, population growth in Sungai Raya District has also increased over the last five years. It is feared that the development will become uncontrollable. The study aims to determine the typology of the area based on the socio-economic aspects in Sungai Raya District. The method used is a scoring analysis that produces three typologies, namely the primary urban peri, secondary urban peri, and rural peri urban. Based on the results of the analysis, it is known that livelihoods, economic resilience index, growth and population density show a relevant relationship between the conditions of peri-urban areas in characterizing urban and rural characters. This is evidenced by the deviation value of the correlation between these variabels, which is $<50 \%$. Furthermore, the scoring analysis showed that $35 \%$ of Sungai Raya District (seven villages) were classified as primary peri urban typology, $10 \%$ (two villages) were secondary peri urban typology and 55\% (eleven villages) were rural peri urban.
\end{abstract}

Keywords: peri-urban; regional typology; socio-economy; Sungai Raya District

\section{Pendahuluan}

Kota sebagai tempat tinggal manusia selalu mengalami perkembangan dalam segala aspek kehidupan seiring perkembangan ilmu pengetahuan, teknologi dan jumlah penduduknya (Yunus, 2008). Hal tersebut mendorong peningkatan akan tuntutan kebutuhan ruang untuk menopang segala aktivitas perkotaan serta masyarakat di dalamnya. Kebutuhan ruang pada kota cepat atau lambat akan sampai pada batas maksimum untuk menampung segala perkembangan dan pembangunan (Muhtar et al., 2019). Sehingga memberikan dampak pada wilayah sekitarnya yang disebut wilayah peri urban. Wilayah peri urban sebagai kawasan peralihan antara aktivitas perkotaan dan pedesaan akan membentuk pola interaksi yang mengalami transisi kegiatan kota desa secara berdampingan (Kurnaianingsih, 2013). Hal tersebut mengindikasikan bahwa wilayah peri urban mengalami perpaduan antara ciri kekotaan dan kedesaan dengan permasalahan yang kompleks (Sari \& Santoso, 2017). Kecamatan Sungai Raya merupakan salah satu wilayah peri urban yang di satu sisi memiliki kenampakan kekotaan, namun di sisi lain memiliki kenampakan kedesaan. Munculnya wilayah peri urban Sungai Raya disebabkan oleh perkembangan Kota Pontianak yang cenderung cepat sehingga memberikan dampak pembangunan yang signifikan hingga wilayah pinggirannya.

Perkembangan Kota Pontianak tidak hanya memberikan dampak dari aspek fisik, namun juga terhadap kondisi sosial ekonomi (Kurnianingsih \& Rudiarto, 2014). Secara umum, kondisi sosial ekonomi di Kecamatan Sungai Raya telah mengalami perubahan dari sifat agaris menjadi nonagraris. Dalam kurun waktu lima tahun, pergeseran masyarakat dari agraris menjadi nonagraris mencapai $20 \%$. Pertumbuhan kegiatan perdagangan dan jasa terutama pada jalan utama Desa meningkat cukup signifikan menggantikan lahan-lahan pertanian. Selain itu, pertumbuhan penduduk di Kecamatan Sungai Raya juga meningkat menjadi 2\% per tahun dalam kurun waktu lima tahun (BPS Kubu Raya, 2019). Berdasarkan posisinya, Kecamatan Sungai Raya memiliki jarak yang dekat dengan pusat pemerintahan maupun perdagangan jasa yang terletak di Kecamatan Pontianak Tenggara. Selain itu, Kecamatan Sungai Raya memiliki arus pergerakan lalu lintas serta tarikan dan bangkitan yang sangat tinggi. Hal ini disebabkan karena Kecamatan Sungai Raya dilalui oleh Jalan Ahmad Yani II yang berfungsi sebagai jalan arteri dengan keberadaan Bandara Internasional Supadio Pontianak, sehingga memiliki tingkat pelayanan yang tinggi (Zulfinanda et al., 2020) 
Faktor-faktor tersebut menyebabkan Kecamatan Sungai Raya menjadi kawasan yang cepat tumbuh dalam kegiatan pembangunan sehingga mempengaruhi munculnya ciri atau sifat perkotaan. Belum lagi didukung dengan kebutuhan lahan di Kota Pontianak yang semakin sedikit serta kebutuhan hidup yang cenderung meningkat. Pembangunan yang terjadi dapat dilihat dari kondisi eksisting desa di Kecamatan Sungai Raya yang berada di pinggiran Kota Pontianak, yaitu pada Desa Sungai Raya dan Desa Kapur. Desa Sungai Raya menunjukkan ciri perkotaan seperti adanya perumahan-perumahan kelas menengah-tinggi, industri-industri yang cukup besar seperti pabrik kayu, serta kegiatan perdagangan dan jasa modern yang menyerupai ciri-ciri kota. Selain itu adanya Transmart Ayani, Markas Komando Daerah Militer XII/Tanjungpura, Rumah Sakit Kartika Husada, dan Kampus III Jurusan Ilmu Keolahragaan Universitas Tanjungpura semakin menunjukkan bahwa telah nampaknya ciri-ciri perkotaan di Desa Sungai Raya. Selanjutnya pada Desa Kapur yang juga berada di pinggiran Kota Pontianak juga mendapat pengaruh langsung dengan ciri-ciri perkotaan, seperti adanya perumahan-perumahan kelas menengah-tinggi dan aktivitas perdagangan toko-toko besar. Pada sisi lain misalnya berdasarkan penggunaan lahan, di Kecamatan Sungai Raya masih memiliki beberapa desa yang didominasi oleh pertanian. Meskipun dari aspek fisik belum terlalu signifikan, hal ini perlu menjadi perhatian untuk dilakukan pencegahan karena wilayah peri urban dapat menimbulkan dampak terhadap aspek lainnya termasuk sosial ekonomi (Kurnianingsih \& Rudiarto, 2014; Rosyidi \& Aulia, 2019). Agar pembangunan lebih terkendali dan berkelanjutan, perlu dilakukan berbagai upaya. Salah satu upaya sebagai langkah awal dalam mengontrol pembangunan di Kecamatan Sungai Raya adalah dengan melakukan analisis pada aspek sosial ekonomi untuk merumuskan tipologi wilayah peri urban sesuai dengan karakteristiknya.

Kajian peri urban pernah dilakukan oleh beberapa peneliti sebelumnya seperti Kurnianingsih \& Rudiarto (2014). yang mencoba mengklasifikasikan dan menganalisis transformasi wilayah peri urban di Kecamatan Kartasura. Hasil kajian ini digunakan sebagai acuan utama peneliti untuk selanjutnya dikomparasikan dengan teori transformasi wilayah dari aspek sosial ekonomi. Rudiarto et al. (2013) pernah meneliti tentang perkembangan kawasan peri urban dengan melihat tipologinya berdasarkan aspek sosial ekonomi. Namun demikian, kajian ini hanya membahas secara parsial pada dua aspek tersebut tanpa secara spesifik mengkorelasikan hubungan keduanya. Lebih lanjut lagi Dewi \& Rudiarto, (2013), di tahun yang sama mengkaji mengenai sejauhmana perubahan fungsi lahan pertanian di wilayah peri urban sehingga dapat di antisipasi peralihannya. Kajian tersebut relevan dengan penelitian ini dari sisi karakteristik wilayah yang mengalami transformasi dari perdesaan ke perkotaan, sehingga dijadikan rujukan dalam memperkaya teori. Mujiandari (2014) dalam penelitiannya melihat perkembangan urban sprawl di Kota Semarang sebagai salah satu rujukan teoritis. Selanjutnya, Sari \& Santoso (2017) menganalisis keterkaitan wilayah peri urban dengan melihat antara wilayah desa dan kota yang ada di sekitarnya. Begitupun Rosyidi \& Aulia (2019), yang melihat keterkaitan kota dan desa dari pendekatan pergerakan orang di kawasan peri urban. Hasil analisis kedua kajian tersebut menjadi referensi dalam melihat hubungan wilayah studi dengan Kota Pontianak sebagai wilayah inti. Selanjutnya, Muhtar et al. (2019) meneliti transformasi wilayah peri urban yang dikaji berdasarkan aspek fisik dan sosial dimana hasil temuan sebagai pengkayaan teori aspek sosial bagi penelitian ini. Paling terbaru, yaitu Zulfinanda et al. (2020) telah melakukan analisis tipologi wilayah peri urban berdasarkan aspek fisik yang merupakan gambaran secara fisik dari lokasi studi untuk dikembangkan lebih lanjut pada penelitian ini. Dari seluruh penelitian sebelumnya, penelitian ini bertujuan untuk mengidentifikasi tipologi wilayah berdasarkan aspek sosial ekonomi di Kecamatan Sungai Raya. Penelitian ini mencoba untuk mengembangkan variabel amatan dalam mengkaji tipologi wilayah peri urban yang dirumuskan berdasarkan pendekatan analisis sosial ekonomi dengan 
mengkomparasikan seluruh teori dan menerapkannya di wilayah Kecamatan Sungai Raya sebagai wilayah peri urban dari Kota Pontianak.

\section{Metode Penelitian}

\section{Metode Pengumpulan Data}

Data primer dan sekunder merupakan metode pengumpulan data yang diterapkan pada kajian ini. Data primer dilakukan melalui observasi dan wawancara. Observasi yang dilakukan adalah untuk mengetahui situasi aktual di lokasi penelitian. Sementara wawancara adalah untuk menggali informasi secara mendalam terkait variabel penelitian. Wawancara dilakukan oleh key informan yang dianggap memahami kondisi perkembangan wilayah studi seperti Camat dan Lurah atau jajarannya, perwakilan tokoh masyarakat tiap desa dan pelaku usaha seperti petani, pedagang, dan pengusaha. Pengumpulan data sekunder dilakukan dengan survei instansional untuk memperoleh data-data terkait kepadatan dan jumlah penduduk, jumlah angkatan kerja, komposisi penduduk menurut mata pencaharian di sektor pertanian serta indeks ketahanan ekonomi.

\section{Metode Analisis Data}

Metode yang digunakan adalah analisis skoring tipologi wilayah peri urban yang dibagi ke dalam primer, sekuder dan rural (Singh, 2011). Analisis skoring digunakan karena penerapannya sangat mudah digunakan namun relevan dengan tujuan penelitian yang ingin melihat klasifikasi tertentu pada suatu wilayah. Skor diberikan pada variabel di setiap wilayah sesuai dengan tingkat klasifikasi peri urban yang telah ditetapkan. Setelah seluruh variabel diberikan skoring, selanjutnya skor setiap wilayah diakumulasi untuk merumuskan tipologi wilayah peri urban. Skor 3 diberikan pada desa yang didominasi oleh ciri kekotaan. Skor 2 diberikan untuk desa yang memiliki ciri kekotaan dan kedesaan sekaligus. Skor 1 diberikan pada desa yang masih didominasi oleh ciri kedesaan. Penentuan kriteria dalam tipologi wilayah peri urban diperoleh dari beberapa teori para ahli, peraturan dan kebijakan terkait, dan asumsi peneliti tentang zonasi wilayah peri urban. Hasil analisis skoring berupa gambaran dan karakter wilayah peri urban maupun tingkatan perkotaan dan perdesaan yang ada pada setiap desa. Proses analisis dilakukan melalui tahapan pertama yaitu melakukan skoring pada masing-masing variabel (Tabel 1) tiap desa di Kecamatan Sungai Raya. Tahap kedua, mengakumulasikan hasil semua variabel pada tiap aspek dari hasil skoring masing-masing desa. Tahap ketiga, mengkompositkan hasil penilaian aspek sosial ekonomi untuk merumuskan tipologi wilayah. Tipologi wilayah digolongkan menjadi peri urban primer, sekunder dan rural. Tahap keempat, masing-masing tipologi direntang (range) berdasarkan perhitungan interval kelas (Sturges, 1926 dalam Sudjana, 1996). Perhitungan interval kelas (Nilai skor tertinggi $=15$; Nilai skor terendah $=5$. Sehingga, pembagian tipologi wilayah peri urban adalah sebagai berikut: Rural peri urban = akumulasi skor antara 5-8; Peri urban sekunder = akumulasi skor antara $9-12$; dan Peri ubran primer $=$ akumulasi skor $>12$. Tahap kelima, setelah mengetahui jangkauan/rentang (range) masing-masing tipologi, selanjutnya penilaian aspek sosial ekonomi setiap desa disesuaikan dengan rentang kelas tersebut. Tahap keenam membuat kesimpulan jenis tipologi tiap desa sesuai dengan klasifikasi di Tahap keempat dan kelima.

\section{Variabel Penelitian}

Variabel yang digunakan dalam pembahasan ini meliputi dua aspek yaitu aspek sosial dan eknomi. Pada aspek sosial melibatkan dua variabel, yaitu kepadatan dan pertumbuhan 
penduduk. Sementara aspek ekonomi terdiri tiga variabel, yang terdiri dari angkatan kerja, mata pencaharian, dan indeks ketahanan ekonomi.

Tabel 1. Variabel Penelitian

\begin{tabular}{|c|c|c|c|c|}
\hline & Variabel & Sub Variabel & Indikator & Skor \\
\hline \multicolumn{5}{|c|}{$\begin{array}{l}\text { Aspek Ekonomi } \\
\end{array}$} \\
\hline \multirow[t]{3}{*}{1.} & Angkatan & Jumlah Angkatan & $>60 \%$ & 3 \\
\hline & Kerja & Kerja $\geq$ Tamatan SMP & $30 \%-60 \%$ & 2 \\
\hline & & & $<30 \%$ & 1 \\
\hline \multirow[t]{3}{*}{2.} & Mata & Persentase Mata & $0 \%-40 \%$ & 3 \\
\hline & Pencaharian & Pencaharian Penduduk & $>40 \%-60 \%$ & 2 \\
\hline & Penduduk & Sektor Pertanian & $>60 \%$ & 1 \\
\hline \multirow[t]{3}{*}{3} & Indeks & Angka Indeks & $>0,8111$ & 3 \\
\hline & Ketahanan & Ketahanan Ekonomi & $0,6389-0,8111$ & 2 \\
\hline & $\begin{array}{l}\text { Ekonomi } \\
\text { (IKE) }\end{array}$ & (IKE) & $<0,6389$ & 1 \\
\hline \multicolumn{5}{|c|}{ Aspek Sosial } \\
\hline \multirow[t]{3}{*}{4.} & Kepadatan & Tingkat Kepadatan & $>3000 \mathrm{jiwa} / \mathrm{km}^{2}$ & 3 \\
\hline & Penduduk & Penduduk & $>1500 \mathrm{jiwa} / \mathrm{km}^{2}-\leq 3000 \mathrm{jiwa} / \mathrm{km}^{2}$ & 2 \\
\hline & & & $\leq 1500 \mathrm{jiwa} / \mathrm{km}^{2}$ & 1 \\
\hline \multirow[t]{3}{*}{5.} & Pertumbuhan & Laju Pertumbuhan & $>2 \%$ & 3 \\
\hline & Penduduk & Penduduk & $1 \%-2 \%$ & 2 \\
\hline & & & $<1 \%$ & 1 \\
\hline
\end{tabular}

Sumber: Kurnaianingsih, 2013; Kurnianingsih \& Rudiarto,2014; Rudiarto et al., 2013 (modifikasi)

\section{Hasil dan Pembahasan \\ Kondisi Sosial Sebagai Pembentuk Wilayah Peri Urban}

Karakteristik wilayah peri urban berdasarkan aspek sosial pada pembahasan ini akan dinilai berdasarkan dua variabel. Variabel tersebut di antaranya yaitu kepadatan dan pertumbuhan penduduk. Aspek sosial dan ekonomi menjadi fokus kajian mengingat bahwa Kecamatan Sungai Raya sebagai wilayah peri urban yang berbatasan langsung dengan Kota Pontianak mengalami dampak yang cukup signifikan terutama pada kondisi sosial ekonomi. Secara umum, kondisi sosial ekonomi di Kecamatan Sungai Raya telah mengalami perubahan dari sifat agaris menjadi nonagraris. Dalam kurun waktu lima tahun, pergeseran masyarakat dari agraris menjadi nonagraris mencapai $20 \%$. Pertumbuhan kegiatan perdagangan dan jasa terutama pada jalan utama desa meningkat cukup signifikan menggantikan lahan-lahan pertanian. Selain itu, pertumbuhan penduduk di Kecamatan Sungai Raya juga meningkat menjadi $2 \%$ pertahun dalam kurun waktu lima tahun.

\section{Kepadatan Penduduk}

Kepadatan penduduk merupakan salah satu indikator pembentuk karakteristik ruang. Semakin padat penduduk pada suatu wilayah, maka semakin tinggi kebutuhan lahan untuk menyediakan kebutuhan dasar masyarakatnya. Dengan demikian, peluang tingginya lahan terbangun dibandingkan lahan tidak terbangun di wilayah tersebut juga semakin besar (Sarwono, 1992). Asumsinya adalah kepadatan penduduk yang tinggi identik dengan sifat perkotaan. Adapun klasifikasi tingkat kepadatan penduduk yaitu kepadatan penduduk tinggi ( $\geq 3000$ jiwa $/ \mathrm{km}^{2}$ ), kepadatan penduduk sedang (1500-3000 $\left.\mathrm{km}^{2}\right)$, kepadatan penduduk rendah $\left(<1500 \mathrm{~km}^{2}\right)$ (Rudiarto et al., 2013). 
Tabel 2. Kepadatan Penduduk Per Desa di Kecamatan Sungai Raya

\begin{tabular}{llrrr}
\hline No. & \multicolumn{1}{c}{ Desa } & $\begin{array}{c}\text { Luas } \\
\text { Wilayah }\left(\mathbf{k m}^{\mathbf{2}}\right)\end{array}$ & $\begin{array}{c}\text { Jumlah Penduduk } \\
\text { (Jiwa) }\end{array}$ & $\begin{array}{c}\text { Kepadatan Penduduk } \\
\left(\mathbf{J i w a}_{\mathbf{k}} \mathbf{k} \mathbf{k m}^{\mathbf{2}}\right)\end{array}$ \\
\hline 1 & Sungai Raya & 3,417 & 17.075 & 4.997 \\
2 & Sungai Ambangah & 34,398 & 6.053 & 176 \\
3 & Arang Limbung & 14,803 & 26.460 & 1.787 \\
4 & Kuala Dua & 37,766 & 29.934 & 793 \\
5 & Tebang Kacang & 39,202 & 4.829 & 123 \\
6 & Sungai Asam & 238,845 & 13.189 & 55 \\
7 & Pulau Limbung & 118,140 & 2.380 & 20 \\
8 & Kapur & 6,085 & 13.931 & 2.290 \\
9 & Gunung Tamang & 124,960 & 3.895 & 15 \\
10 & Sungai Bulan & 60,984 & 3.415 & 56 \\
11 & Limbung & 38,784 & 17.437 & 450 \\
12 & Teluk Kapuas & 3,324 & 13.864 & 4.171 \\
13 & Madu Sari & 4.427 & 138 \\
14 & Mekar Sari & 31,997 & 11.710 & 212 \\
15 & Mekar Baru & 55,358 & 7.609 & 775 \\
16 & Sungai Raya Dalam & 9,817 & 22.182 & 1.864 \\
17 & Parit Baru & 11,901 & 32.523 & 2.448 \\
18 & Pulau Jambu & 13,284 & 771 & 24 \\
19 & Kalibandung & 32,807 & 2.014 & 17 \\
20 & Muara Baru & 118,936 & 1.083 & 6 \\
\hline
\end{tabular}

Berdasarkan Tabel 2, Desa Sungai Raya merupakan wilayah dengan tingkat kepadatan terbesar. Hal ini disebabkan karena Desa Sungai Raya merupakan wilayah yang langsung berbatasan dengan Kota Pontianak sehingga mendapatkan dampak bagi perkembangan penduduk Kota Pontianak. Selanjutnya yang tergolong ke dalam tingkat kepadatan tinggi hingga sedang yaitu Desa Teluk Kapuas, Kapur, Parit Baru, Sungai Raya Dalam dan Arang Limbung. Desa-desa tersebut juga merupakan desa yang mengalami dampak secara langsung bagi perkembangan ruang yang disebabkan karena adanya gejala urban sprawl. Fenomena ini menimbulkan munculnya titik-titik permukiman baru yang tumbuh secara linier di sepanjang jalan. Semakin berkembangnya penduduk kota yang terjadi secara terus-menerus dan dalam waktu yang lama menyebabkan kota tidak dapat lagi mengakomodir aktivitas masyarakat di dalamnya (Dewi \& Rudiarto, 2013; Mujiandari, 2014). Sebagaimana yang diketahui bahwa kota secara administratif memiliki daya tamping yang terbatas, maka perhatian dari beberapa masyarakat kota teralihkan ke wilayah pinggiran kota terdekat. Akibatnya timbul kecenderungan pertumbuhan penduduk yang tinggi sehingga menyebabkan kepadatan penduduk pada daerah pinggirannya juga semakin tinggi.

Lebih dari itu, desa-desa yang tergolong dalam tipe kepadatan tinggi hingga sedang tersebut juga dilalui oleh Sungai Kapuas yang menjadi awal tumbuhnya permukiman di Kota Pontianak hingga berkembang sampai keluar wilayah. Secara historis, DAS merupakan cikal bakal dari pertumbuhan dan perkembangan kota sebagai sebuah karakteristik permukiman awal yang selaras dengan kondisi lingkungan sosial masyarakat Indonesia (Hamidah et al., 2014). Selanjutnya, sebagai jalur lalu lintas perdagangan skala regional, Sungai Kapuas menjadi daya tarik bagi terbentuknya embrio pusat-pusat permukiman yang kemudian menjalar hingga bagian dalam wilayah. Berdasarkan sejarahnya, Desa Parit Baru dan Sungai Raya Dalam, merupakan wilayah pemekaran dari Desa Sungai Raya yang dimekarkan pada tahun 2011. Hal ini menyebabkan sebagian penduduk berpindah ke dalam dua Desa tersebut hingga secara masif membangun permukiman-permukiman baru yang berpengaruh pada tingginya kepadatan penduduk. 
Pada desa-desa yang terletak jauh dari kota seperti, Desa Gunung Tamang, Desa Pulau Limbung Desa Kalibandung, Desa Pulau Jambu dan Desa Muara Baru memiliki tingkat kepadatan penduduk yang rendah. Selain luas wilayahnya yang besar, desa-desa tersebut juga memiliki akses dan fasilitas yang sulit dijangkau. Hal ini menyebabkan desadesa kepadatan rendah cenderung didominasi oleh lahan tidak terbangun. Sebagaimana yang disampaikan oleh Arsandi bahwa infrastruktur merupakan salah satu faktor bagi pertumbuhan dan kepadatan penduduk. Semakin baik pelayanan infrastruktur dasar disuatu wilayah, maka semakin laju migrasi penduduk yang masuk (Arsandi et al., 2017). Dengan demikian, semakin tinggi kepadatan penduduk wilayah tersebut.

\section{Pertumbuhan Penduduk}

Pertumbuhan penduduk adalah perbedaan jumlah penduduk akibat terjadinya perubahan yang terjadi dari tahun dasar ketahun sebelumnya dan dinyatakan dengan persentase. Adanya pertumbuhan penduduk dipengaruhi beberapa hal seperti migrasi keluar masuk serta tingkat kelahiran dan kematian. Kedua faktor tersebut yang dapat menyebabkan bertambah atau berkurangnya jumlah penduduk dari suatu wilayah (Weeks, 2012). Kecamatan Sungai Raya sebagai wilayah peri urban dari Kota Pontianak selalu mengalami penambahan penduduk tiap tahun. Menurut Pryor, klasifikasi laju pertumbuhan penduduk terdiri dari tiga kelas, yaitu pertumbuhan penduduk tinggi $(>3 \%)$, sedang $(2 \%$ $3 \%$ ) dan rendah $(<2 \%)$ (Yunus, 2008).

Tabel 3. Laju Pertumbuhan Penduduk Per Desa di Kecamatan Sungai Raya

\begin{tabular}{rlrrrrrr}
\hline No. & \multicolumn{1}{c}{ Desa } & $\mathbf{2 0 1 4 -}$ & $\mathbf{2 0 1 5 -}$ & $\mathbf{2 0 1 6 -}$ & $\mathbf{2 0 1 7}-$ & $\mathbf{2 0 1 8 -}$ & $\begin{array}{c}\text { Rata - } \\
\text { Rata }\end{array}$ \\
\hline 1 & Sungai Raya & $5,51 \%$ & $7,99 \%$ & $-3,69 \%$ & $2,30 \%$ & $4,82 \%$ & $3,39 \%$ \\
2 & Sungai Ambangah & $-0,64 \%$ & $-2,03 \%$ & $1,18 \%$ & $6,05 \%$ & $0,70 \%$ & $1,05 \%$ \\
3 & Arang Limbung & $3,41 \%$ & $-0,23 \%$ & $2,34 \%$ & $5,93 \%$ & $0,81 \%$ & $2,45 \%$ \\
4 & Kuala Dua & $1,76 \%$ & $-4,21 \%$ & $2,68 \%$ & $5,71 \%$ & $1,11 \%$ & $1,41 \%$ \\
5 & Tebang Kacang & $-1,30 \%$ & $11,52 \%$ & $-0,83 \%$ & $-2,77 \%$ & $1,81 \%$ & $1,69 \%$ \\
6 & Sungai Asam & $-2,76 \%$ & $14,55 \%$ & $1,80 \%$ & $0,61 \%$ & $0,55 \%$ & $2,95 \%$ \\
7 & Pulau Limbung & $-1,67 \%$ & $11,54 \%$ & $-3,88 \%$ & $-2,20 \%$ & $-2,28 \%$ & $0,30 \%$ \\
8 & Kapur & $7,10 \%$ & $2,47 \%$ & $5,17 \%$ & $11,17 \%$ & $5,20 \%$ & $6,22 \%$ \\
9 & Gunung Tamang & $-12,96 \%$ & $1,59 \%$ & $4,82 \%$ & $12,54 \%$ & $0,58 \%$ & $1,31 \%$ \\
10 & Sungai Bulan & $4,08 \%$ & $-8,26 \%$ & $0,51 \%$ & $6,57 \%$ & $1,76 \%$ & $0,93 \%$ \\
11 & Limbung & $6,89 \%$ & $1,78 \%$ & $0,82 \%$ & $-4,84 \%$ & $-0,84 \%$ & $0,76 \%$ \\
12 & Teluk Kapuas & $-0,54 \%$ & $-4,27 \%$ & $-0,21 \%$ & $4,38 \%$ & $-1,32 \%$ & $-0,39 \%$ \\
13 & Madu Sari & $5,73 \%$ & $-0,66 \%$ & $1,95 \%$ & $7,16 \%$ & $2,76 \%$ & $3,39 \%$ \\
14 & Mekar Sari & $6,66 \%$ & $-16,51 \%$ & $3,32 \%$ & $6,79 \%$ & $1,19 \%$ & $0,29 \%$ \\
15 & Mekar Baru & $6,80 \%$ & $-0,60 \%$ & $8,87 \%$ & $19,58 \%$ & $11,05 \%$ & $9,14 \%$ \\
16 & Sungai Raya Dalam & $3,04 \%$ & $-1,01 \%$ & $0,83 \%$ & $8,51 \%$ & $-1,03 \%$ & $2,07 \%$ \\
17 & Parit Baru & $0,64 \%$ & $6,82 \%$ & $-0,92 \%$ & $-4,39 \%$ & $1,29 \%$ & $0,69 \%$ \\
18 & Pulau Jambu & $5,35 \%$ & $-5,84 \%$ & $4,31 \%$ & $-0,65 \%$ & $0,26 \%$ & $0,69 \%$ \\
19 & Kalibandung & $5,15 \%$ & $10,62 \%$ & $-2,68 \%$ & $-7,04 \%$ & $-0,35 \%$ & $1,14 \%$ \\
20 & Muara Baru & $9,42 \%$ & $-13,22 \%$ & $4,70 \%$ & $6,35 \%$ & $-0,55 \%$ & $1,34 \%$ \\
\hline
\end{tabular}

Tabel 3 menunjukan bahwa Kecamatan Sungai Raya mengalami pertumbuhan yang fluktuatif dalam rentang waktu 6 tahun. Rata-rata pertumbuhan penduduk selama enam tahun tersebut adalah 2,04 atau tergolong sedang. Terdapat desa-desa yang tergolong dalam pertumbuhan penduduk tinggi hingga sedang di antaranya adalah Desa Sungai Raya, Kapur, Mekar Baru, Arang Limbung, Madu Sari, Sungai Asam dan Sungai Raya Dalam. Ini menunjukkan bahwa ketujuh desa tersebut memiliki ciri perkotaan. Tingginya laju pertumbuhan penduduk dapat disebabkan oleh beberapa hal, seperti harga lahan yang 


\section{Analisis Sosial Ekonomi Pembentuk Tipologi Wilayah Peri Urban Kecamatan Sungai Raya ...}

cenderung murah dibandingkan dengan Kota Pontianak. Sebagaimana yang telah dikemukakan pada beberapa penelitian seperti Dewi \& Rudiarto (2013), Mujiandari (2014), dan Putra \& Pradoto (2016), bahwa selain faktor transportasi dan komunikasi, perkembangan wilayah perkotaan dan sekitarnya juga tidak terlepas dari pengaruh faktor lokasi dan harga lahan. Selanjutnya, selain dekat dan berbatasan langsung dengan Kota Pontianak, desa-desa tersebut memiliki fasilitas penunjang yang lengkap serta aksesibilitas yang mudah untuk menjangkau perkotaan yang menyebabkan kebutuhan masyarakat dapat terpenuhi. Hal ini menarik minat masyarakat untuk memilih dan tinggal di wilayah tersebut, sehingga memunculkan pusat-pusat pertumbuhan baru.

Perkembangan pembangunan yang pesat di kawasan pinggiran sehingga tumbuh menjadi pusat pertumbuhan baru dapat dilihat dari tingginya preferensi masyarakat dalam memilih tempat tinggal karena faktor kenyamanan dan kemudahan pelayanan infrastruktur (Arsandi et al., 2017; Mardiansjah et al., 2018). Lebih dari itu, angka kelahiran yang tinggi juga mempengaruhi tingginya pertumbuhan penduduk di wilayah tersebut. Hal ini selaras dengan teori kependudukan bahwa semakin mudah dan terlayaninya infrastruktur disuatu wilayah, maka semakin tinggi migrasi masuk yang menyebabkan pertumbuhan penduduk semakin tinggi. Begitupun dengan pelayanan Kesehatan yg baik, akan menyebabkan semakin baik pula tingkat kesehatan masyarakat yang berpengaruh pada tingginya mordibilitas (Weeks, 2012).

Desa-desa yang tergolong ke dalam laju pertumbuhan penduduk rendah di antaranya adalah Desa Sungai Ambangah, Tebang Kacang, Kuala Dua, Pulau Limbung, Sungai Bulan, Gunung Tamang, Limbung, Mekar Sari, Parit Baru, Pulau Jambu, Teluk Kapuas, Kalibandung dan Muara Baru. Seluruh Desa dengan pertumbuhan penduduk rendah merupakan wilayah yang cukup jauh dari Kota Pontianak dengan ketersediaan infrastruktur yang terbatas. Seperti pada teori diatas bahwa desa-desa dengan pertumbuhan penduduk rendah merupakan wilayah yang didominasi oleh lahan tidak terbangun yang kurang diminati oleh masyarakat untuk ditinggali (Arsandi et al., 2017; Mardiansjah et al., 2018).

\section{Kondisi Ekonomi Sebagai Pembentuk Wilayah Peri Urban}

Karakteristik wilayah peri urban berdasarkan aspek ekonomi pada pembahasan ini akan dinilai berdasarkan tiga variabel, yaitu angkatan kerja, mata pencaharian sektor pertanian, dan indeks ketahanan ekonomi (IKE) (Kurnaianingsih, 2013; Rudiarto et al., 2013).

\section{Angkatan Kerja}

Tenaga kerja merupakan kemampuan manusia untuk bekerja dalam menghasilkan barang atau jasa yang memiliki nilai ekonomis sehingga berguna bagi kebutuhan masyarakat. Pada umumnya secara fisik, kemampuan orang bekerja dapat diukur dan dinilai berdasarkan usia. Orang yang mampu bekerja adalah mereka yang berada dalam usia kerja atau produktif. Penduduk perkotaan identik dengan penduduk yang produktif. Ketenagakerjaan dalam perspektif wilayah peri urban memiliki peranan penting dalam menentukan apakah wilayah desa tersebut termasuk wilayah yang memiliki ciri kekotaan atau tidak. Tenaga kerja yang berdomisili diwilayah pedesaan didominasi oleh orang-orang dengan karakteristik masyarakat yang tidak mengutamakan pendidikan secara formal. Oleh karena itu, banyak dari mereka yang tidak bersekolah atau mengenyam pendidikan formal, tidak tamat SD dan hanya berijazah SD. Sementara tenaga kerja perkotaan, cenderung memiliki pendidikan setingkat SLTP ke atas (Setiawan, 2006). Secara umum, angkatan

kerja di Kecamatan Sungai Raya terdiri dari bermacam latar belakang pendidikan, mulai dari yang tidak tamat SD hingga yang menyelesaikan pendidikan sampai bangku sarjana. 
Adapun wilayah yang memiliki jumlah angkatan kerja minimal tamatan SMP dengan persentase $>60 \%$ tergolong ke dalam ciri didominasi perkotaan. Wilayah yang memiliki jumlah angkatan kerja minimal tamatan SMP dengan persentase antara 30\% - 60\% tergolong memiliki ciri kekotaan maupun kedesaan. Sedangkan wilayah yang memiliki jumlah angkatan kerja minimal tamatan SMP dengan persentase di bawah 30\% tergolong wilayah yang didominasi oleh ciri kedesaan.

Tabel 4. Jumlah Angkatan Kerja Kecamatan Sungai Raya

\begin{tabular}{clrrrrr}
\hline No. Desa & $\begin{array}{r}\text { Jumlah } \\
\text { Angkatan } \\
\text { Kerja (Jiwa) }\end{array}$ & $\begin{array}{c}\text { Jumlah Angkatan } \\
\text { Kerja } \begin{array}{c}\text { Tamatan } \\
\text { SD (Jiwa) }\end{array}\end{array}$ & $\begin{array}{c}\text { \% } \\
\text { Jumlah Angk. } \\
\text { Kerja } \geq \text { Tamatan } \\
\text { SMP (Jiwa) }\end{array}$ & \% \\
\hline 1 & Sungai Raya & 6,177 & 1,170 & $19 \%$ & 5,007 & $81 \%$ \\
2 & Sungai Ambangah & 3,824 & 2,095 & $55 \%$ & 1,729 & $45 \%$ \\
3 & Arang Limbung & 6,598 & 1,130 & $17 \%$ & 5,468 & $83 \%$ \\
4 & Kuala Dua & 4,622 & 2,220 & $48 \%$ & 2,402 & $52 \%$ \\
5 & Tebang Kacang & 3,857 & 2,237 & $58 \%$ & 1,620 & $42 \%$ \\
6 & Sungai Asam & 4,172 & 2,252 & $54 \%$ & 1,920 & $46 \%$ \\
7 & Pulau Limbung & 1,235 & 585 & $47 \%$ & 650 & $53 \%$ \\
8 & Kapur & 3,278 & 688 & $21 \%$ & 2,590 & $79 \%$ \\
9 & Gunung Tamang & 1,196 & 500 & $42 \%$ & 696 & $58 \%$ \\
10 & Sungai Bulan & 3,286 & 1,475 & $45 \%$ & 1,811 & $55 \%$ \\
11 & Limbung & 4,500 & 1,080 & $24 \%$ & 3,420 & $76 \%$ \\
12 & Teluk Kapuas & 4,025 & 864 & $21 \%$ & 3,161 & $79 \%$ \\
13 & Madu Sari & 3,208 & 2,233 & $70 \%$ & 975 & $30 \%$ \\
14 & Mekar Sari & 4,907 & 1,930 & $39 \%$ & 2,977 & $61 \%$ \\
15 & Mekar Baru & 3,774 & 1,525 & $40 \%$ & 2,249 & $60 \%$ \\
16 & Sungai Raya Dalam & 5,313 & 1,845 & $35 \%$ & 3,468 & $65 \%$ \\
17 & Parit Baru & 6,192 & 1,902 & $31 \%$ & 4,290 & $69 \%$ \\
18 & Pulau Jambu & 240 & $49 \%$ & 252 & $51 \%$ \\
19 & Kalibandung & 492 & 450 & $12 \%$ & 3,213 & $88 \%$ \\
20 & Muara Baru & 3,663 & 473 & $62 \%$ & 295 & $38 \%$ \\
\hline
\end{tabular}

Dari Tabel 4 diketahui bahwa sebagian besar jumlah angkatan kerja yang memiliki minimal ijazah SMP hingga tingkat pendidikan yang lebih tinggi pada 20 desa menunjukkan persentase lebih dari 50\%. Ini menunjukkan bahwa jumlah angkatan kerja mulai menunjukkan ciri perkotaan. Besar kecilnya jumlah angkatan kerja pada setiap desa berbanding lurus dengan ketersediaan fasilitas pendidikan yang ada pada setiap desa di Kecamatan Sungai Raya. Desa yang memiliki fasilitas pendidikan yang lengkap dan memadai tentunya akan memiliki banyak angkatan kerja yang berlatar belakang SMA hingga sarjana. Desa-desa tersebut seperti Desa Sungai Raya, Kapur, Sungai Raya Dalam, Arang Limbung, Teluk Kapuas, Mekar Baru, Kalibandung, Parit Baru, dan Limbung. Jumlah angkatan kerja yang berlatar belakang sarjana pada desa-desa tersebut mencapai $>300$ orang. Sedangkan desa yang memiliki angkatan kerja yang didominasi oleh penduduk tamatan SD ke bawah menandakan bahwa kurangnya fasilitas pendidikan serta rendahnya aksesibilitas di wilayah tersebut menuju ke sarana Pendidikan. Hal tersebut yang menyebabkan minat belajar dan partisipasi sekolah menjadi rendah. Sebagaimana yang diketahui bahwa keberadaan fasilitas pendidikan mempengarhui tingkat kemiskinan sebagai dampak dari rendahnya tingkat pendidikan masyarakat disuatu wilayah (Aristina et al., 2017). 


\section{Mata Pencaharian Menurut Sektor Pertanian}

Mata pencaharian masyarakat dapat menunjukkan karakteristik suatu wilayah, apakah termasuk dalam ciri-ciri perdesaan atau perkotaan. Hal ini berlaku pada wilayah peri urban sebagai wilayah gradasi antara kota dan desa. Hal tersebut akan terjadi pergeseran mata pencaharian yang diakibatkan oleh pengaruh dari kota yang berbatasan langsung. Transformasi pekerjaan yang biasanya terjadi pada wilayah peri urban adalah mata pencaharian di sektor pertanian menjadi nonpertanian. Pertanian merupakan salah satu ciri-ciri dari mata pencaharian yang menjadi andalan bagi masyarakat desa untuk memenuhi kebutuhannya (Setiawan, 2006; Hardati et al., 2014). Seperti halnya Kabupaten Kubu Raya, pada akhir tahun 2019 mendapatkan penghargaan sebagai percontohan penerapan pertanian digital di Kalimantan. Ini menandakan bahwa Kabupaten Kubu Raya bertumpu pada sektor pertanian.

Kecamatan Sungai Raya sebagai salah satu wilayah yang terdapat di Kabupaten Kubu Raya hingga saat ini masih bergantung pada usaha pertanian. Namun demikian, terdapat desa terutama desa-desa yang berdekatan dengan Kota Pontianak sedang mengalami pembangunan secara besar-besaran pada beberapa tahun terakhir. Kecamatan Sungai Raya sedang dalam masa pembangunan permukiman dan fasilitas-fasilitas pendukungnya yang sangat masif. Dengan adanya pembangunan permukiman pastinya terdampak pada lahan pertanian di Kecamatan Sungai Raya yang dikonversi menjadi lahan permukiman. Hal ini disebabkan oleh mulai masuknya pengaruh kekotaan seperti akses yang sangat mudah untuk mencapai Kota Pontianak, sehingga banyak penduduk yang lebih memilih bekerja di kota ataupun mendirikan bisnis perindustrian dan perdagangan jasa di Kecamatan Sungai Raya.

Tabel 5. Mata Pencaharian Masyarakat Sektor Pertanian Kecamatan Sungai Raya

\begin{tabular}{clrrr}
\hline No & \multicolumn{1}{c}{ Desa } & $\begin{array}{c}\text { Jumlah Penduduk } \\
\text { Bekerja (Jiwa) }\end{array}$ & $\begin{array}{c}\text { Penduduk Mata Pencaharian } \\
\text { Pertanian (Jiwa) }\end{array}$ & Persentase \\
\hline 1 & Sungai Raya & 5,084 & 265 & $5.2 \%$ \\
2 & Sungai Ambangah & 3,441 & 2,862 & $83.2 \%$ \\
3 & Arang Limbung & 4,877 & 1,380 & $28.3 \%$ \\
4 & Kuala Dua & 4,379 & 2,483 & $56.7 \%$ \\
5 & Tebang Kacang & 3,286 & 2,971 & $90.4 \%$ \\
6 & Sungai Asam & 2,784 & 2,150 & $77.2 \%$ \\
7 & Pulau Limbung & 610 & 510 & $83.6 \%$ \\
8 & Kapur & 3,271 & 1,630 & $49.8 \%$ \\
9 & Gunung Tamang & 543 & 450 & $82.9 \%$ \\
10 & Sungai Bulan & 3,284 & 2,858 & $87.0 \%$ \\
11 & Limbung & 4,745 & 1,005 & $21.2 \%$ \\
12 & Teluk Kapuas & 6,777 & 705 & $10.4 \%$ \\
13 & Madu Sari & 3,178 & 2,759 & $86.8 \%$ \\
14 & Mekar Sari & 2,685 & 2,490 & $92.7 \%$ \\
15 & Mekar Baru & 2,058 & 1,211 & $58.8 \%$ \\
16 & Sungai Raya Dalam & 5,588 & 410 & $7.3 \%$ \\
17 & Parit Baru & 5,512 & 2,396 & $43.5 \%$ \\
18 & Pulau Jambu & 199 & 170 & $85.4 \%$ \\
19 & Kalibandung & 1,565 & 1,530 & $97.8 \%$ \\
20 & Muara Baru & 806 & 729 & $90.4 \%$ \\
\hline
\end{tabular}

Tabel 5 merepresentasikan telah masuknya pengaruh perkotaan pada beberapa desa yang diberikan Kota Pontianak sebagai wilayah yang langsung berbatasan dengan Kecamatan Sungai Raya. Desa Sungai Raya dan Desa Sungai Raya Dalam menunjukkan 
bahwa pertanian bukan lagi menjadi tumpuan utama perekonomian masyarakat melainkan dari sektor nonpertanian, seperti pegawai negeri, pedagang, polisi, TNI, pengrajin dan sebagainya. Namun demikian, masih terdapat desa yang bergantung pada sektor pertanian, seperti Desa Kalibandung, Desa Sungai Asam, Desa Tebang Kacang, Desa Sungai Ambangah, Desa Sungai Bulan, dan Desa Mekar Sari. Ini menandakan bahwa pengaruh sifat kekotaan terhadap Kecamatan Sungai Raya dibatasi dengan jarak tempuh dan kemudahan akses pada lokasi kerja. Masyarakat di bagian timur wilayah, masih memilih bekerja di sektor pertanian daripada harus bekerja ke kota disektor nonpertanian. Ditambah dengan standar pendidikan menjadi syarat untuk bekerja sebagai pegawai ataupun modal yang besar untuk membuka bisnis di perkotaan.

\section{Indeks Ketahanan Ekonomi (IKE)}

Indeks Ketahanan Ekonomi (IKE) merupakan suatu metode penilaian yang digunakan untuk melihat perkembangan ekonomi suatu desa. IKE ini adalah salah satu dari tiga indikator untuk merumuskan Indeks Desa Membangun (IDM) selain dari Indeks Ketahanan Sosial (IKS) dan Indeks Ketahanan Lingkungan (IKL). Wilayah peri urban yang muncul di Kecamatan Sungai Raya berpengaruh terhadap nilai IKE pada setiap desa. Dapat diasumsikan bahwa semakin tinggi nilai IKE, maka semakin dekat dengan ciri perkotaan. Klasifikasi IKE yang akan digunakan untuk menilai data yaitu >0,8111 (Tinggi), 0,63890,8111 (Sedang) dan <0,6389 (Rendah) (Sturges, 1926 dalam Sudjana, 1996).

Tabel 6. Indeks Ketahanan Ekonomi Masyarakat Kecamatan Sungai Raya

\begin{tabular}{|c|c|c|}
\hline No. & Desa & IKE \\
\hline 1 & Sungai Raya & 0,9833 \\
\hline 2 & Sungai Ambangah & 0,6833 \\
\hline 3 & Arang Limbung & 0,8667 \\
\hline 4 & Kuala Dua & 0,8833 \\
\hline 5 & Tebang Kacang & 0,5667 \\
\hline 6 & Sungai Asam & 0,6667 \\
\hline 7 & Pulau Limbung & 0,5667 \\
\hline 8 & Kapur & 0,8333 \\
\hline 9 & Gunung Tamang & 0,5500 \\
\hline 10 & Sungai Bulan & 0,6333 \\
\hline 11 & Limbung & 0,8833 \\
\hline 12 & Teluk Kapuas & 0,7500 \\
\hline 13 & Madu Sari & 0,4833 \\
\hline 14 & Mekar Sari & 0,5833 \\
\hline 15 & Mekar Baru & 0,7667 \\
\hline 16 & Sungai Raya Dalam & 0,8667 \\
\hline 17 & Parit Baru & 0,9167 \\
\hline 18 & Pulau Jambu & 0,4667 \\
\hline 19 & Kalibandung & 0,4667 \\
\hline 20 & Muara Baru & 0,5167 \\
\hline
\end{tabular}

Tabel 6 menunjukkan bahwa desa-desa yang termasuk dalam klasifikasi IKE tinggi antara lain Desa Sungai Raya, Desa Kuala Dua, Desa Arang Limbung, Desa Kapur, Desa Limbung, Desa Sungai Raya Dalam, dan Desa Parit Baru. Kedelapan desa ini memiliki ciri perkotaan yang lebih mendominasi dibanding dengan ciri pedesaan. Selanjutnya desa yang tergolong sedang di antaranya adalah Desa Gunung Tamang, Desa Teluk Kapuas, Desa Sungai Ambangah, Desa Sungai Asam, Desa Sungai Bulan, dan Desa Mekar Baru. Sisanya termasuk dalam klasifikasi IKE rendah. 


\section{Analisis Sosial Ekonomi Pembentuk Tipologi Wilayah Peri Urban Kecamatan Sungai Raya ...}

Berdasarkan fakta di lapangan desa-desa dengan IKE tinggi merupakan wilayah yang hampir memenuhi indikasi pada dimensi ekonomi. Hal tersebut dapat dilihat pada sarana serta prasarana ekonomi yang sangat memadai. Adapun beberapa sarana dan prasarana ekonomi yang terdapat di Kecamatan Sungai Raya seperti Mall Transmart yang menjadi pusat perbelanjaan yang terdapat di Desa Sungai Raya. Mall ini juga menjadi salah satu sarana bagi masyarakat Kecamatan Sungai Raya maupun Kubu Raya untuk memenuhi kebutuhan hidup. Bahkan tidak sedikit masyarakat Kota Pontianak yang dilayani oleh mall tersebut sehingga menciptakan bangkitan dan tarikan yang cukup tinggi. Selanjutnya terdapat Bank KCU BCA Kubu Raya di Desa Sungai Raya sebagai bagian dari lembaga perbankan umum. Selain itu, hotel, usaha kedai makanan, restoran, dan penginapan telah banyak ditemukan di berbagai desa di Kecamatan Sungai Raya, seperti Hotel Harmony Inn di Desa Sungai Raya Dalam, Qubu Resort di Desa Parit Baru. Desa - desa yang memiliki nilai IKE menengah ke bawah juga terdapat sarana dan prasaran ekonomi seperti restoran, pasar, dan pusat perbelanjaan. Namun, jumlah dan skala pelayanannya tidak sebanyak dan sebesar fasilitas ekonomi di wilayah dengan kriteria IKE tinggi. Dengan demikian, jumlah dan pelayanan infrastrukur dapat mempengaruhi pertumbuhan ekonomi wilayah termasuk dalam meningkatkan ketahanan ekonomi masyarakatnya (Maryaningsih et al., 2014).

\section{Tipologi Wilayah Peri Urban Berdasarkan Aspek Sosial Ekonomi}

Kajian tipologi wilayah peri urban berdasarkan aspek sosial ekonomi dilakukan dengan analisis scoring melalui variabel yang telah dijelaskan pada pembahasan sebelumnya. Analisis scoring ini menggunakan teori - teori dari penelitian terdahulu terkait tipologi wilayah peri urban (Kurnaianingsih, 2013; Rudiarto et al., 2013). Skor yang telah didapatkan dari kelima variabel pada aspek sosial ekonomi akan diakumulasikan secara keseluruhan. Hasil akumulasi skor akan menghasilkan tipologi wilayah peri urban pada semua desa di Kecamatan Sungai Raya. Tiap desa akan digolongkan ke dalam tipologi peri urban primer (PUP), peri urban sekunder (PUS) atau rural peri urban (RPU). Skor 3 diberikan pada desa yang sudah tergolong ke dalam wilayah yang didominasi oleh ciri kekotaan dibanding dengan ciri kedesaannya. Skor 2 diberikan pada desa yang ciri kekotaan dan kedesaannya saling mempengaruhi. Skor 3 diberikan pada desa yang masih didominasi oleh ciri kedesaan.

Tabel 7 menjelaskan bahwa berdasarkan aspek sosial ekonomi, terdapat tujuh desa atau 35\% wilayah Kecamatan Sungai Raya tergolong peri urban primer, yakni Sungai Raya Dalam, Desa Sungai Raya, Arang Limbung, Kapur, Teluk Kapuas, Limbung, dan Parit Baru. Sementara 2 desa atau 10\% tergolong tipologi peri urban sekunder yaitu Desa Kuala Dua dan Mekar Baru. Sedangkan desa dengan tipologi rural peri urban adalah sebanyak 11 desa atau 55\% yakni Tebang Kacang, Sungai Bulan, Sungai Asam, Desa Sungai Ambangah, Gunung Tamang, Madu Sari, Mekar Sari, Pulau Limbung, Pulau Jambu, Kalibandung dan Muara Baru.

Berdasarkan analisis kesesuaian hubungan antar variabel dengan karakteristik tipologi wilayah peri urban di Kecamatan Sungai Raya diketahui bahwa terdapat variasi antara aspek sosial dan ekonomi (Gambar 1, Gambar 2, dan Gambar 3). Pada aspek sosial, variabel kepadatan dan pertumbuhan penduduk memiliki hubungan yang tergolong cukup tinggi dengan tipologi wilayah peri urban, dimana tingkat kesesuaian antar variabel masingmasing sebesar $65 \%$ dan 55\%. Dengan demikian, deviasi atau penyimpangan tipologi pada variabel kepadatan dan pertumbuhan penduduk dengan karakteristik wilayah peri urban kurang dari 50\%, yaitu sebesar masing-masing 35\% dan 45\%. Sedangkan pada aspek ekonomi, hanya variabel mata pencaharian dan indeks ketahanan ekonomi yang memiliki hubungan tinggi dengan tipologi wilayah peri urban, yaitu masing-masing sebesar $90 \%$ dan $80 \%$. Hal ini menunjukkan bahwa deviasi atau penyimpangan tipologi pada variabel mata pencaharian dan indeks ketahanan ekonomi dengan karakteristik wilayah peri urban kurang 
dari $50 \%$, yaitu sebesar $10 \%$ dan $20 \%$. Sementara variabel angkatan kerja kurang memiliki hubungan yang kuat dengan tipologi wilayah peri urban dimana tingkat kesesuaiannya hanya $45 \%$ atau memiliki deviasi sebesar $55 \%$. Dengan demikian, rata-rata deviasi antara keseluruhan variabel dengan tipologi wilayah peri urban di Kecamatan Sungai Raya tergolong rendah, yaitu sebesar 33\%. Hal tersebut mengindikasikan bahwa seluruh variabel pada aspek sosial ekonomi secara bersama-sama dapat menjelaskan tipologi wilayah peri urban sebesar $67 \%$.

Tabel 7. Tipologi Wilayah Peri Urban Berdasarkan Aspek Sosial Ekonomi Kecamatan Sungai Raya

\begin{tabular}{|c|c|c|c|c|c|c|c|c|c|c|c|c|}
\hline \multirow{4}{*}{ Desa } & \multicolumn{12}{|c|}{ Tipologi Wilayah Peri Urban } \\
\hline & \multicolumn{4}{|c|}{ Aspek Sosial } & \multicolumn{6}{|c|}{ Aspek Ekonomi } & \multirow{2}{*}{\multicolumn{2}{|c|}{$\begin{array}{l}\text { Kesimpulan } \\
\text { Sosial } \\
\text { Ekonomi }\end{array}$}} \\
\hline & \multicolumn{2}{|c|}{$\begin{array}{l}\text { Kepadatan } \\
\text { Penduduk }\end{array}$} & \multicolumn{2}{|c|}{$\begin{array}{l}\text { Pertumbuhan } \\
\text { Penduduk }\end{array}$} & \multicolumn{2}{|c|}{$\begin{array}{c}\text { Angkatan } \\
\text { Kerja }\end{array}$} & \multicolumn{2}{|c|}{$\begin{array}{c}\text { Mata } \\
\text { Pencaharian } \\
\text { Sektor } \\
\text { Pertanian }\end{array}$} & \multicolumn{2}{|c|}{$\begin{array}{c}\text { Indek } \\
\text { Ketahanan } \\
\text { Ekonomi }\end{array}$} & & \\
\hline & Skor & Tipologi & Skor & Tipologi & Skor & Tipologi & Skor & - Tipologi & Skor & rTipologi & Skor & Tipologi \\
\hline Sungai Raya & 3 & PUP & 3 & PUP & 3 & PUP & 3 & PUP & 3 & PUP & 3 & PUP \\
\hline $\begin{array}{l}\text { Sungai } \\
\text { Ambangah }\end{array}$ & 1 & RPU & 1 & RPU & 2 & PUS & 1 & RPU & 2 & PUS & 1 & RPU \\
\hline $\begin{array}{l}\text { Arang } \\
\text { Limbung }\end{array}$ & 2 & PUS & 2 & PUS & 3 & PUP & 3 & PUP & 3 & PUP & 3 & PUP \\
\hline Kuala Dua & 1 & RPU & 1 & RPU & 2 & PUS & 2 & PUS & 3 & PUP & 2 & PUS \\
\hline $\begin{array}{l}\text { Tebang } \\
\text { Kacang }\end{array}$ & 1 & RPU & 1 & RPU & 2 & PUS & 1 & RPU & 1 & RPU & 1 & RPU \\
\hline $\begin{array}{l}\text { Sungai } \\
\text { Asam }\end{array}$ & 1 & RPU & 2 & PUS & 2 & PUS & 1 & RPU & 2 & PUS & 1 & RPU \\
\hline $\begin{array}{l}\text { Pulau } \\
\text { Limbung }\end{array}$ & 1 & RPU & 1 & RPU & 2 & PUS & 1 & RPU & 1 & RPU & 1 & RPU \\
\hline Kapur & 1 & RPU & 3 & PUP & 3 & PUP & 2 & PUS & 3 & PUP & 3 & PUP \\
\hline $\begin{array}{l}\text { Gunung } \\
\text { Tamang }\end{array}$ & 1 & RPU & 1 & RPU & 2 & PUS & 1 & RPU & 1 & RPU & 1 & RPU \\
\hline $\begin{array}{l}\text { Sungai } \\
\text { Bulan }\end{array}$ & 1 & RPU & 1 & RPU & 2 & PUS & 1 & RPU & 1 & RPU & 1 & RPU \\
\hline Limbung & 1 & RPU & 1 & RPU & 3 & PUP & 3 & PUP & 3 & PUP & 3 & PUP \\
\hline $\begin{array}{l}\text { Teluk } \\
\text { Kapuas }\end{array}$ & 3 & PUP & 1 & RPU & 3 & PUP & 3 & PUP & 2 & PUS & 3 & PUP \\
\hline Madu Sari & 1 & RPU & 3 & PUP & 2 & PUS & 1 & RPU & 1 & RPU & 1 & RPU \\
\hline Mekar Sari & 1 & RPU & 1 & RPU & 2 & PUS & 1 & RPU & 1 & RPU & 1 & RPU \\
\hline Mekar Baru & 1 & RPU & 3 & PUP & 2 & PUS & 2 & PUS & 2 & PUS & 2 & PUS \\
\hline $\begin{array}{l}\text { Sungai Raya } \\
\text { Dalam }\end{array}$ & 2 & PUS & 2 & PUS & 3 & PUP & 3 & PUP & 3 & PUP & 3 & PUP \\
\hline Parit Baru & 2 & PUS & 1 & RPU & 3 & PUP & 2 & PUS & 3 & PUP & 3 & PUP \\
\hline Pulau Jambu & 1 & RPU & 1 & RPU & 2 & PUS & 1 & RPU & 1 & RPU & 1 & RPU \\
\hline Kalibandung & 1 & RPU & 1 & RPU & 3 & PUP & 1 & RPU & 1 & RPU & 1 & RPU \\
\hline Muara Baru & 1 & RPU & 1 & RPU & 2 & PUS & 1 & RPU & 1 & RPU & 1 & RPU \\
\hline
\end{tabular}


319 Analisis Sosial Ekonomi Pembentuk Tipologi Wilayah Peri Urban Kecamatan Sungai Raya ...

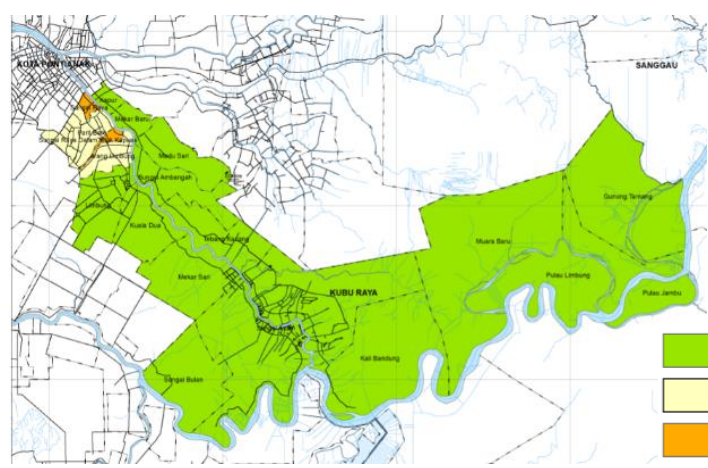

(a)

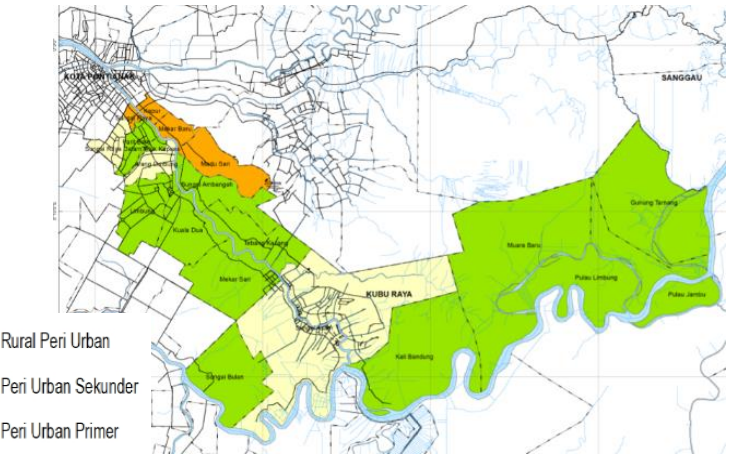

(b)

Gambar 1. Peta Tipologi Wilayah Peri Urban Berdasarkan (a) Aspek Kepadatan dan (b) Pertumbuhan Penduduk Kecamatan Sungai Raya

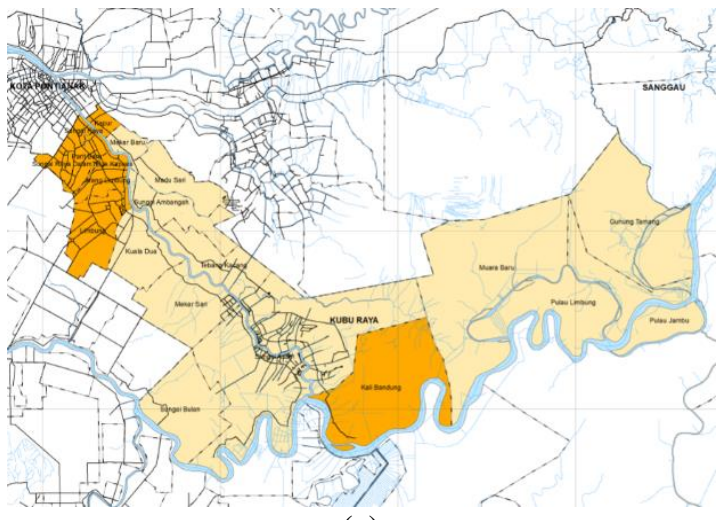

(ii)

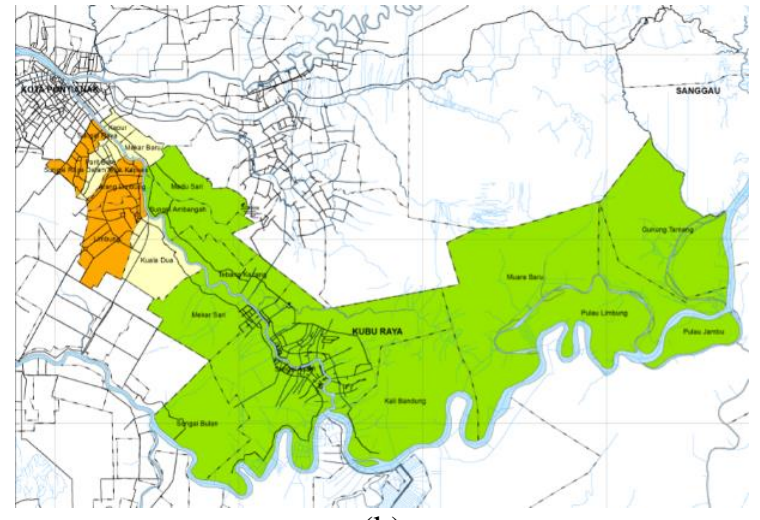

(b)

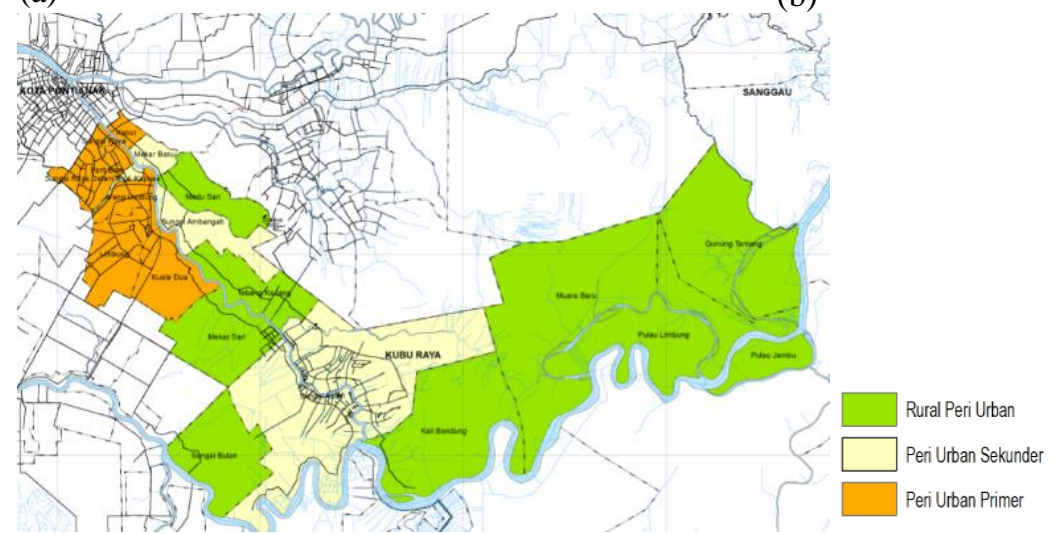

(c)

Gambar 2. Peta Tipologi Wilayah Peri Urban Berdasarkan (a) Aspek Angkatan Kerja, (b) Mata Pencaharian dan (c) Indeks Ketahanan Ekonomi Kecamatan Sungai Raya 


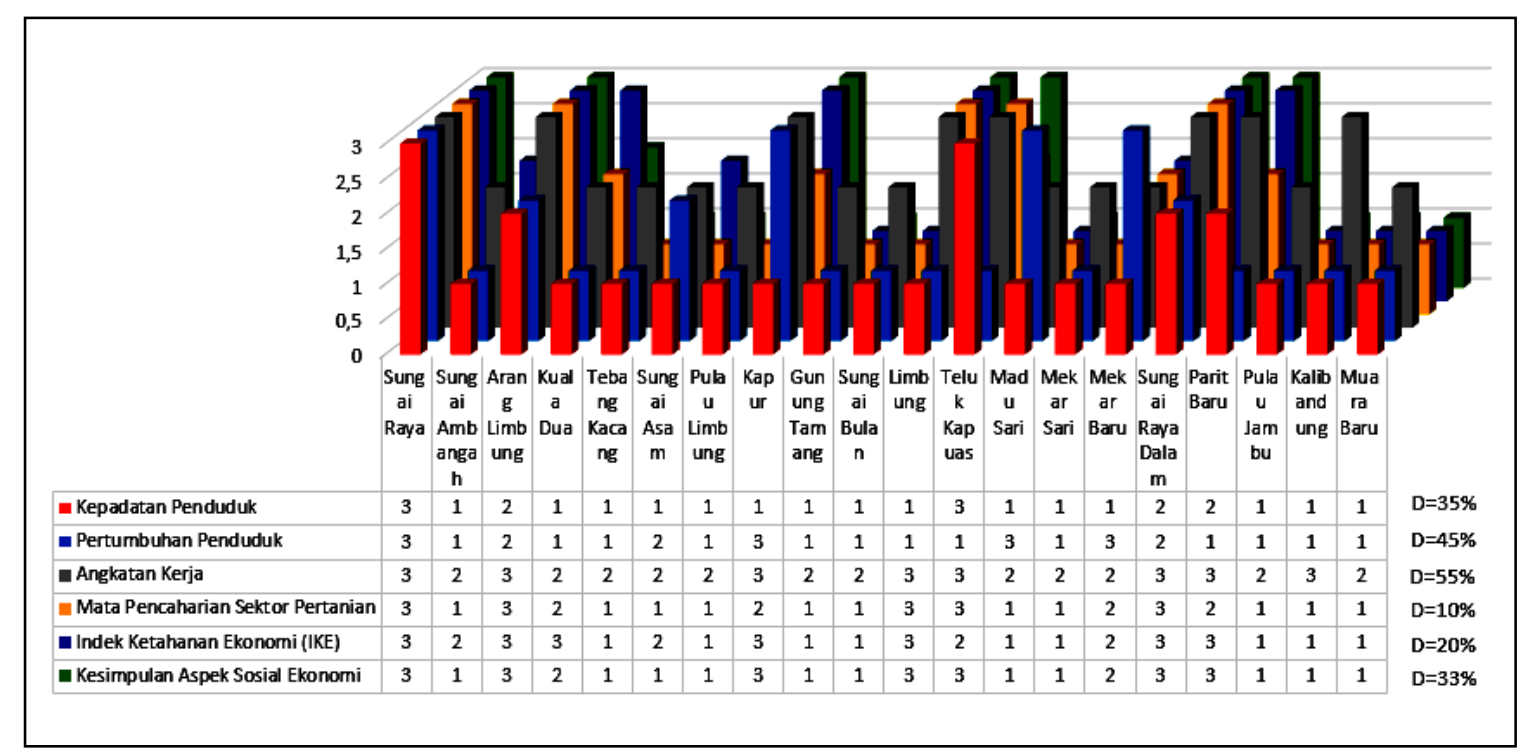

Gambar 3. Analisis Kesesuaian Hubungan Antar Variabel Dengan Tipologi Peri Urban

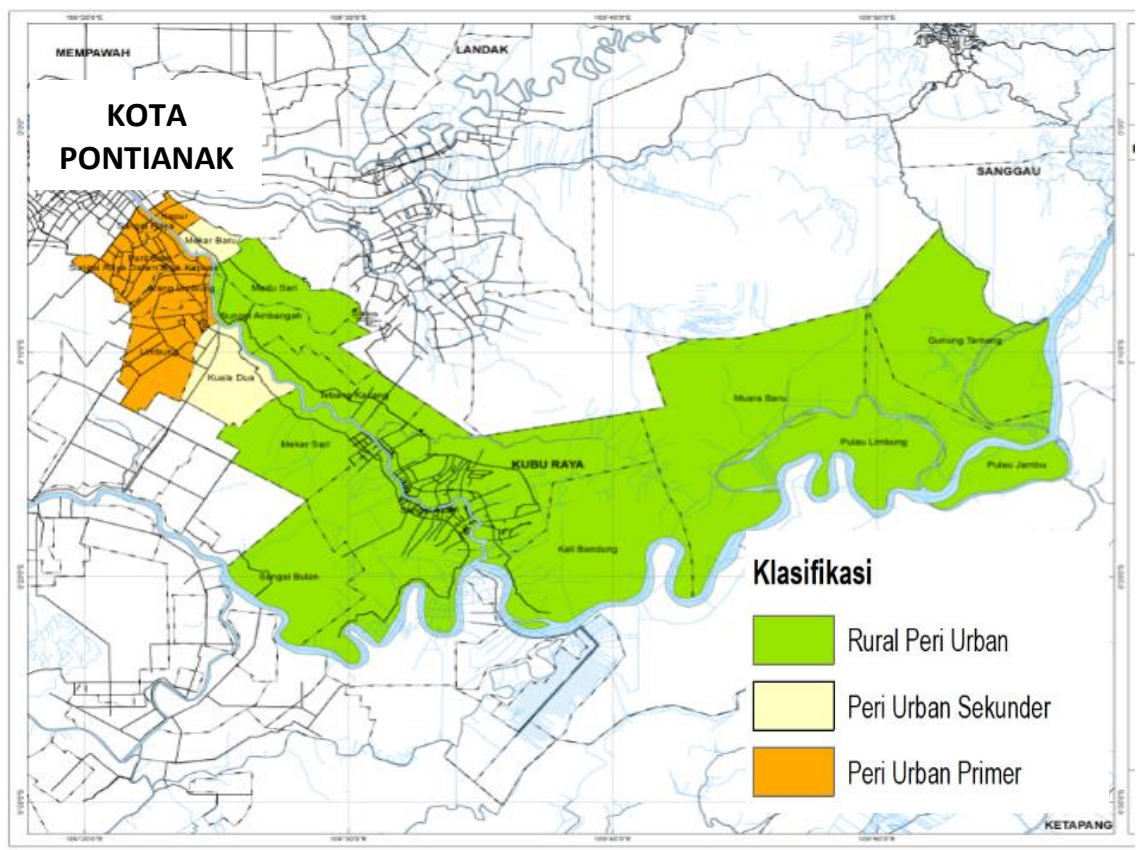

\section{Gambar 4. Peta Tipologi Wilayah Peri Urban Berdasarkan Aspek Sosial Ekonomi Kecamatan Sungai Raya}

Gambar 4 menjelaskan bahwa seluruh desa dengan tipologi peri urban primer berada diwilayah bagian barat kecamatan, yaitu berdekatan dengan Kota Pontianak sebagai kota inti yang memiliki nilai ekonomi lahan cukup potensial. Perubahan spatial peri urban yang mempengaruhi struktur pola umum wilayah dapat ditentukan berdasarkan nilai ekonomis lahan serta jalan utama desa yang terdapat di wilayah peri urban menuju pusat perkotaan. Begitupun dengan jarak dari desa-desa di wilayah peri urban menuju pusat kota induk dan 
jarak desa-desa tersebut ke akses utama kota induk (Nandi \& Dewiyanti, 2019). Semakin dekat jarak-jarak tersebut, maka semakin besar peluang suatu wilayah berubah fungsi menjadi perkotaan atau memiliki sifat perkotaan (peri urban primer). Lebih dari itu, sebagian besar wilayah peri urban primer berada dibarat selatan Kecamatan Sungai Raya karena adanya pengaruh lokasi yang berdekatan dengan kawasan pemerintahan dan pusat perdagangan jasa yang dominan berada di Kecamatan Pontianak Tenggara dan Kecamatan Pontianak Selatan. Selain itu, faktor aksesibiitas dimana sebagaian besar desa-desa dengan tipologi peri urban primer dilalui oleh Jalan Ahmad Yani II yang berfusngsi sebagai jalan arteri serta Jalan Ya'M Sabran sebagai jalan kolektor primer yang menghubungkan antara Kabupaten Mempawah-Kota Pontianak-Kabupaten Kubu Raya dengan tingkat pelayanan tinggi memperkuat terbentuknya tipologi wilayah peri urban primer. Peningkatan pelayanan transportasi dan jarak dengan pusat kota merupakan salah satu faktor perkembangan wilayah perdesaan menjadi wilayah perkotaan (Nandi \& Dewiyanti, 2019).

Berdasarkan ketersediaan sarana prasarana, diketahui bahwa desa-desa tersebut merupakan wilayah pusat-pusat pertumbuhan baru yang dilengkapi dengan saran prasarana perkotaan. Sarana prasarana perkotaan yang ada di antaranya seperti Mall Transmart, Bandar Udara Internasional Supadio, Kampus III UNTAN, Rumah Sakit Kartika Husada, pusat grosir indomarco, pertokoan besar, perhotelan, restoran dan lain sebagainya dengan skala pelayanan kota hingga regional. Hal tersebut yang mempengaruhi preferensi penduduk untuk tinggal dan menetap sehingga perkembangan ruang semakin pesat dan berpengaruh pada terbentuknya kawasan peri urban primer di Kecamatan Sungai Raya. Seperti yang diketahui bahwa ketersediaan infrastruktur yang lengkap dapat mempengaruhi pertumbuhan wilayah sehingga terjadi transformasi ruang dari sifat perdesaan menjadi perkotaan (Nandi \& Dewiyanti, 2019). Hal ini disebabkan karena ketersediaan fasilitas umum dapat memberi kemudahan bagi aspek-aspek kehidupan sehingga berpengaruh besar terhadap proses perubangan fungsi lahan dan pembentuk pusat-pusat pertumbuhan baru. Hal tersebut berpengaruh pada pilihan masyarakat maupun berbagai fungsi perkotaan untuk memilih lokasi disuatu wilayah (Yunus, 2001).

\section{Kesimpulan}

Hasil analisis menggambarkan bahwa mata pencaharian, indeks ketahanan ekonomi, pertumbuhan serta kepadatan penduduk menunjukkan kecenderungan yang relevan terhadap kondisi wilayah peri urban baik dalam menjelaskan sifat dan ciri perkotaan maupun pedesaan. Artinya bahwa terdapat hubungan yang selaras antara gambaran aspek sosial ekonomi dengan zonasi peri urban di Kecamatan Sungai Raya. Selanjutnya, dari persebaran tipologi mengindikasikan bahwa jarak dengan kota inti (Kota Pontianak) sangat berpengaruh terhadap terbentuknya tipologi wilayah peri urban. Kedekatan jarak dengan kota inti menyebabkan wilayah pinggiran Kota Pontianak memiliki potensi lahan dengan nilai ekonomi yang cukup tinggi. Hal tersebut mempengaruhi daya tarik bagi tumbuhnya permukiman sehingga muncul pusat-pusat pertumbuhan baru. Selain itu, dukungan fasilitas perkotaan yang lengkap menyebabkan wilayah-wilayah pinggiran Kota Pontianak mengalami transformasi spasial yang cukup tinggi dari kegiatan pertanian menjadi nonpertanian.

Hasil temuan pada penelitian ini dapat menjadi pengayaan terhadap teori transformasi wilayah pada aspek sosial ekonomi, khususnya wilayah Kalimantan dengan karakteristik yang berbeda dengan Pulau Jawa. Misalnya kondisi mata pencaharian dimana sebagian besar telah mengalami pergeseran dari agraris ke nonagraris untuk kawasan pedesaan. Hal ini mengingat bahwa lahan pertanian di Wilayah Kalimantan tidak begitu dominan menggambarkan kawasan perdesaan dibandingkan dengan Pulau Jawa. Karakteristik lahan tidak terbangun di Kalimantan cenderung didominasi oleh hutan dan 
semak dibandingkan lahan pertanian. Dengan demikian, kebijakan yang dilakukan pemerintah untuk mengintervensi pembangunan wilayah harus relevan dengan karakterstik wilayahnya.

\section{Daftar Pustaka}

Aristina, I., Budhi, M. K., Wirathi, I. G. A. ., \& Darsana, I. B. (2017). Pengaruh tingkat pendidikan, pengangguran dan pertumbuhan ekonomi terhadap kemiskinan di Provinsi Bali. E-Jurnal Ekonomi Pembangunan Universitas Udayana, 6(5), 677-704.

Arsandi, A., R, D., Ismiyati, I., \& Hermawan, F. (2017). Dampak pertumbuhan penduduk terhadap infrastruktur di Kota Semarang. Jurnal Karya Teknik Sipil S1 Undip, 64), 1-14.

BPS Kubu Raya. (2019). Kecamatan Sungai Raya dalam angka 2019. Kabupaten Kubu Raya: Badan Pusat Statistik.

Dewi, N. K., \& Rudiarto, I. (2013). Identifikasi alih fungsi lahan pertanian dan kondisi sosial ekonomi masyarakat daerah pinggiran di Kecamatan Gunungpati Kota Semarang. Jurnal Wilayah dan Lingkungan, 1(2), 175188. doi:10.14710/jwl.1.2.175-188.

Hamidah, N., Rijanta, R., Setiawan, B., \& Marfai, M. A. (2014). Urban riverside settlement model case: Kahayan riverside settlement, Palangkaraya. Jurnal Pemukiman, 9(1), 17-27.

Hardati, P., Rijanta, R., \& Ritohardoyo, S. (2014). Struktur mata pencaharian penduduk dan diversifikasi perdesaan di Kecamatan Tengaran Kabupaten Semarang. Jurnal Geografi: Media Informasi Pengembangan dan Profesi Kegeografian, 11(1), 84-95. doi:10.15294/jg.v11i1.8042.

Kurnaianingsih, N. A. (2013). Klasifikasi tipologi zona perwilayahan wilayah peri-urban di kecamatan Kartasura, Kabupaten Sukoharjo. Jurnal Wilayah dan Lingkungan, 1(3), 251-264. doi:10.14710/jwl.1.3.251-264.

Kurnianingsih, N. A., \& Rudiarto, I. (2014). Analisis Transformasi wilayah peri-urban pada aspek fisik dan sosial ekonomi (Kecamatan Kartasura). Jurnal Pembangunan Wilayah \& Kota, 19(3), 265-277. doi:10.14710/pwk.v10i3.7784.

Mardiansjah, F. H., Handayani, W., \& Setyono, J. S. (2018). Pertumbuhan penduduk perkotaan dan perkembangan pola distribusinya pada Kawasan Metropolitan Surakarta. Jurnal Wilayah dan Lingkungan, 6(3), 215-23. doi:10.14710/jwl.6.3.215-233.

Maryaningsih, N., Hermansyah, O., \& Savitri, M. (2014). Pengaruh infrastruktur terhadap pertumbuhan ekonomi Indonesia. Buletin Ekonomi Moneter dan Perbankan, 171), 61-97. doi:10.21098/bemp.v17i1.44.

Muhtar, G. A., Dangkua, T., \& Matalaptu, I. (2019). Transformasi wilayah peri-urban Kota Makassar Ghinia. Journal of Humanity \& Social Justice, 1(2), 168-184. doi:10.1007/978-3-030-02006-4_186-1.

Mujiandari, R. (2014). Perkembangan urban sprawl Kota Semarang pada wilayah Kabupaten Demak tahun 2001-2012. Jurnal Wilayah dan Lingkungan, 2(2), 129-142. doi:10.14710/jwl.2.2.129-142.

Nandi, \& Dewiyanti, V. R. (2019). Urban sprawl development in Eastern Bandung Region. IOP Conference Series: Earth and Environmental Science, 286(1), 1-8. doi:10.1088/1755-1315/286/1/012031.

Nations, U. (1973). Determinants and consequences of population trends. New York: Department of Economics and Social Affairs. Retrieved from: https://www.un.org/development/desa/pd/es/node/3006.

Putra, D. R., \& Pradoto, W. (2016). Pola dan faktor perkembangan pemanfaatan lahan di Kecamatan Maranggen, Kabupaten Demak. Jurnal Pengembangan Kota, 4(1), 67-75. doi10.14710/jpk.4.1.67-75.

Rosyidi, A. Z., \& Aulia, B. U. (2019). Pola keterkaitan kota-desa dari segi pergerakan orang antara Kota Mojokerto dengan wilayah peri urban di Kabupaten Mojokerto. Jurnal Teknik ITS, 8(2), 96-101. doi:10.12962/j23373539.v8i2.48393.

Rudiarto, I., Handayani, W., Pigawati, B., \& Pangi, P. (2013). Zona peri-urban Semarang Metropolitan: Perkembangan dan tipologi sosial ekonomi. Jurnal Tataloka, 15(2), 116-128. doi:10.14710/tataloka.15.2.116-128.

Sari, K. D. R., \& Santoso, E. B. (2017). Analisis keterkaitan wilayah peri urban di Kabupaten Gresik dengan wilayah desa-kota di sekitarnya. Jurnal Teknik ITS, 6(2), 2-7. doi:10.12962/j23373539.v6i2.24971.

Sarwono, S. W. (1992). Psikologi lingkungan. Grasindo. 
Setiawan, I. (2006). Peran sektor pertanian dalam penyerapan tenaga kerja Indonesia. Jurnal Geografi GEA, 6(1), 1-6. doi:10.17509/gea.v6i1.1733.g1183.

Singh, R. P. B. (2011). Changing rural landscape in the peri-urban zone of varanasi and strategies for sustainable planning. In IFLA APR CLC International Symposium (pp.169-184).

Sudjana. (1996). Metode statistika. Sinar Baru Algasindo.

Weeks, J. R. (2012). Population: An introduction to concepts and issues, (10th ed.). San Diego State University.

Yunus, H. S. (2001). Perubahan pemanfaatan lahan di daerah pinggiran kota kasus di pinggiran Kota Yogyakarta. Fakultas Geografi, Universitas Gadjah Mada.

Yunus, H. S. (2008). Dinamika wilayah peri urban (determinan masa depan kota) (I). Pustaka Belajar.

Zulfinanda, H., Pratiwi, N. N., \& Wulandari, A. (2020). Analisis tipologi wilayah peri urban berdasarkan aspek fisik di kecamatan Sungai Raya Kabupaten Kubu Raya. JeLAST: Jurnal PWK, Laut, Sipil, Tambang, 73), 1-10. doi:10.26418/jelast.v7i3.42689. 